\title{
The Crimean Bridge and Its Effect in Vladimir Putin's Image as a Strong Leader
}

\author{
Sampson M. Nathanailidis* \\ PhD Candidate - Political Sciences, Taras Shevchenko National University of Kyiv
}

*Corresponding Author: Sampson M. Nathanailidis, PhD Candidate - Political Sciences, Taras Shevchenko National University of Kyiv

\begin{abstract}
This paper analyses the repercussions of Putin's actions particularly focusing on how Putin has manipulated the construction of the Crimean Bridge to advance his agenda and image of being Russia's only capable leader. Consequently, it contends that he has used the Crimean Bridge on three major fronts to perpetrate his image as a strong leader.
\end{abstract}

Keywords: Crimea Bridge, National Identity, Political Power, Sense of Ownership

\section{INTRODUCTION}

Russia's history in the modern age has been one surrounded with political and economic intrigue. Since the end of the Second World War, Russia has experienced both success and failure in arguably equal measure. Shortly after the war in which it had emerged as one of the world leaders, it was engaged in a Cold War that would precipitate one of the worst economic crises in history and ultimately lead to the disbandment of the Union of Soviet Socialist Republics (USSR) into 15 independent republics. In the ensuing years after the collapse of the USSR, Russia struggled to recover its political and economic supremacy in the global arena. However, the rise of Vladimir Putin to power in 1999 as one of the most publicly acclaimed presidents in recent history signalled the beginning of a new era for Russia. Russia's economy recovered significantly with a $72 \%$ increase in purchasing power. Putin's hard lined domestic and foreign policies also saw Russia regain most of its economic and political glory in the global arena ${ }^{1}$. However, after his inauguration into his third presidential term in 2012, his approval ratings dropped significantly ${ }^{2}$. His third and fourth presidential terms which he is now serving have been marred by allegations of widespread corruption, political suppression, human rights violations, voting irregularities, internal political strife, and global conflict ${ }^{3}$. Most recently, the annexation of Crimea and construction of the Crimean Bridge in 2014 and 2018 respectively serve as an impeccable example of Putin's situation and by extension Russia. On one hand, his decisions are lauded by his supporters and promote his image as a strong leader while on the other hand, his policies and actions are criticized by the opposition and international community leading to more conflict and serious negative economic ramifications through sanctions ${ }^{4}$.

\section{BACKGROUND OF THE CRIMEAN BRIDGE CRISIS}

Since the collapse of the USSR and subsequent independence, Ukraine has struggled to sustain political stability. The country has for years found itself torn between fostering economic and political ties with the European Union (E.U) or supporting Russian ties and possibly reintegrating with Russia.

\footnotetext{
${ }^{1}$ Luhn, Alec. 2015. "15 Years Of Vladimir Putin: 15 Ways He Has Changed Russia And The World". The Guardian. https://www.theguardian.com/world/2015/may/06/vladimir-putin-15-ways-he-changed-russia-world. ${ }^{2}$ Fokht, Elizaveta. 2019. "Is Putin's Popularity In Decline?". BBC News. https://www.bbc.com/news/worldeurope-48674705.

${ }^{3}$ Times, The. 2019. "Russia Moves To Decriminalize 'Unavoidable' Corruption, Following Putin's Proposal". The Moscow Times. https:/www.themoscowtimes.com/2019/01/29/russia-moves-decriminalizeunavoidable-corruption-following-putins-proposal-a64316.

${ }^{4}$ Goncharenko, Roman. 2019. "Vladimir Putin's 'Crimea Effect' Ebbs Away 5 Years On | DW | 15.03.2019". DW.COM. https://www.dw.com/en/vladimir-putins-crimea-effect-ebbs-away-5-years-on/a47941002.
} 
The first two Ukrainian presidents, Leonid Kravchuk and Leonid Kuchma remained relatively neutral on the matter openly harbouring ties with both the EU and Russia. However, the election of Viktor Yushchenko, a pro-western supporter, in 2005 initiated a course of events that would lead to today's turmoil in Ukraine ${ }^{5}$. During his tenure, Ukrainian relations with Russia drastically deteriorated as he sort to integrate Ukraine with the EU as opposed to Russia. Economic and political standoffs between Ukraine and Russia saw the Ukrainian economy suffer and tensions raise. This set the ground for his ouster in 2010 when pro-Russian opposition leader Viktor Yanukovych was elected as president. However, his pro-Russian policies became unpopular leading to the Ukrainian revolution in 2014 which promptly led to widespread instability in Ukraine ${ }^{6}$. In the aftermath, Russia annexed Crimea as war erupted in other regions seeking independence particularly in Donetsk and Lugansk where war still rages on today. The instability in Ukraine set the stage for Putin to annex Crimea and thereafter construct the Crimean Bridge using it as a tool to assert his leadership and boost ratings amid his declining popularity in Russia.

\section{How Putin USEd The CRimean BRidge}

\subsection{To Create Conflict}

Political conflict is often a strategy used by many politicians to ascend to power or maintain political control in the wake of declining support. In such situations, political figureheads and leaders fabricate conflicts and wars to polarize the population and spread fear. They then invent solutions to solve the conflicts coming off as saviours and painting a false image of strong leadership. While this tactic has been widely used by dictatorial regimes in developing countries to maintain control, Putin's construction of the Crimean Bridge is arguably an indirect use of political conflict to garner support as a strong leader ${ }^{7}$. The Crimean Bridge has destabilized Ukraine on both the political and economic front. According to Bond, Olearchyk, and Seddon (2019), Russia's control of the bridge has starved Ukraine of huge import and export revenue by curtailing free movement of cargo ships between the Black sea and the ports of Berdyansk and Mariupol ${ }^{8}$. Ships that took around 7 hours to navigate through the Kerch Strait, over which the Crimean Bridge spans, now take more than 40hours since inauguration of the bridge. Moreover, cargo handling in the Ukrainian ports of Mariupol and Berdyansk has fallen by more than $60 \%$ translating to over $\$ 400$ million in lost revenue for Ukraine ${ }^{9}$. Although Putin and his administration have maintained that there is no ill-will for the delays which they term as necessary security precautions, the economic impact of the bridge on the Ukrainian economy is most likely a destabilization tactic. Like in most cases, when the eventual economic impact of the Crimean Bridge is felt by the Ukrainian population, the blame is directed to the government as the people are blinded to the external interference by Putin and his administration. The ensuing instability puts Putin in a particularly advantageous position to emerge as the much needed conflict mediator by offering military assistance to contain the conflict in Ukraine. Already in Crimea, Putin's popularity among the local population has increased dramatically since the Crimean Bridge was opened. Moreover, there is growing support in the warring Donbass Region in Eastern Ukraine for a possible reunification with Russia ${ }^{10}$. Collectively, the economic and political ramifications of the Crimean Bridge have served to paint Putin as a strong leader in and outside Russia who is dedicated to restore civility in the volatile region.

\footnotetext{
${ }^{5}$ Karatnycky, Adrian. 2005. "Ukraine's Orange Revolution". Foreign Affairs 84 (2): 35. doi:10.2307/20034274.

${ }^{6}$ Kolst $\varnothing$, Pål. 2016. "Crimea Vs. Donbas: How Putin Won Russian Nationalist Support—And Lost It Again". Slavic Review 75 (3): 702-725. doi:10.5612/slavicreview.75.3.0702.

${ }^{7}$ Fokht, Elizaveta. 2019. "Is Putin's Popularity In Decline?". BBC News. https://www.bbc.com/news/worldeurope-48674705.

${ }^{8}$ Bond, David, Roman Olearchyk, and Max Seddon. 2019. "Russian Bridge To Crimea Strangles Ukraine Ports | Financial Times". Ft.Com. https://www.ft.com/content/f5c68dd4-765c-11e9-be7d-6d846537acab.

${ }^{9}$ Bond, David, Roman Olearchyk, and Max Seddon. 2019. "Russian Bridge To Crimea Strangles Ukraine Ports | Financial Times". Ft.Com. https://www.ft.com/content/f5c68dd4-765c-11e9-be7d-6d846537acab.

${ }^{10}$ Times, The. 2019. "Rebel Leader Says East Ukraine Wants To Join Russia - The Moscow Times". The

Moscow Times. https://www.themoscowtimes.com/2019/04/09/rebel-leader-says-east-ukraine-wants-to-joinrussia-a65162.
} 


\subsection{Imposition of Authority}

Secondly, the approach of utilizing brute force and disregard for international ridicule in building the Crimean Bridge forms a background against which Putin is seen as a strong and exceptional leader. Although Putin's ascension to power was marred by allegations of masterminding the 1999 apartment house buildings, it was his ensuing hard line retaliation against the alleged Chechen terrorist perpetrators that cemented his presidency and image as the strong leader that Russia needed ${ }^{11}$. Similarly his hard line approach in building the Crimean Bridge has had a similar effect. In building the Crimean Bridge, Putin imposed his authority by disregarding pressure from Europe and the West that aimed to persuade Russia to lay off claims of Crimea. The extensive use of military authority and precautions to protect the bridge from water and air attacks that include anti-missile systems and combat divers has also served to paint Putin as a force to reckon ${ }^{12}$. Further, Putin has extensively sold off the bridge as a unifying symbol in Russia that represents the people's interest to be united. Since his first tenure as President, Putin has attracted popular support through his philosophy of concentrating political power and re-nationalization of the energy sector. The construction of the Crimean Bridge has served to advance this popular philosophy. The insurmountable pressure and the cost, political or otherwise of maintaining it has also served to promote his image as a strong leader who will go at great lengths to protect the interest of his people regardless of global critique. In so doing, Putin essentially paints any opposition to the bridge as being pro-western and against the best interest of the Russian people giving him even more leverage to emerge as the hero and protector of Russian interest against western interference and sabotage.

\subsection{Political Scheme}

Finally, Putin has used the Crimean Bridge as a political tool to send out a clear message to the global community and Russian opposition. In essence, Putin insinuates that he is clearly incharge and that even seemingly impossible projects can be accomplished under his strong leadership. Hodge (2018) notes that the bridge carries more symbolism than the traffic it is intended to carry across the Kerch Strait ${ }^{13}$. In particular, the construction of the bridge has played into an intricate web of political machinations that are cumulatively meant to improve Putin's image in and outside Russia. Most notably, it cements the annexation of Crimea as a final and irreversible decision despite opposition from Europe and the West painting Putin as an unshakable force. Although Russia has been adversely affected by economic sanctions owing to Putin's hard stand, the decision to construct the Crimean Bridge also gives him an upper hand in re-negotiating terms for their dismissal. The economic power that Russia holds over Ukraine through the Crimean Bridge is undeniable. The bridge has already adversely affected port operations in Ukraine leading to the loss of billions in lost revenue and perished goods. Figures indicate that Ukraine has lost nearly $\$ 400$ million in the first six months since the bridge was opened ${ }^{14}$. In so doing, Russia is at an advantageous position to arm-twist Ukraine into agreeing to trade deals. Furthermore, the economic ramifications of the bridge on Ukraine are likely to lead to escalating instability in Eastern Ukraine which is expected to draw the attention of the international community keen on preventing further Russian annexation. Such instability and interest from the international community would similarly give Putin an upper hand in re-negotiating for the dismissal of sanctions in return of Russia's neutrality ${ }^{15}$.

In yet another political scheme to paint Putin as the ideal leader, the Crimean Bridge has evoked support from Russian citizens who are grateful for the re-integration of one of the most popular

\footnotetext{
${ }^{11}$ Satter, David. 2016. "Vladimir Putin \& 1999 Russian Apartment-House Bombings -- Was Putin Responsible? - By David Satter". Hudson.Org. https://www.hudson.org/research/12750-vladimir-putin-1999-russianapartment-house-bombings-was-putin-responsible.

${ }^{12}$ Lourie, Richard. 2018. "Putin'S Bridge Over Troubled Waters". The Globe And Mail. https://www.theglobeandmail.com/opinion/article-putins-bridge-over-troubled-waters/.

${ }^{13}$ Hodge, Nathan. 2018. "Russia's Bridge To Crimea: A Metaphor For The Putin Era". CNN. https://edition.cnn.com/2018/05/15/europe/russia-crimea-bridge-intl/index.html.

${ }^{14}$ The Moscow Times. 2019. "Russia's Crimean Annexation Cost Ukrainian Ports \$400M - FT - The Moscow Times". The Moscow Times. https://www.themoscowtimes.com/2019/05/17/russias-crimean-annexation-costukrainian-ports-400m-ft-a65625.

${ }^{15}$ Beznosiuk, Max. 2019. "The Ukraine Conflict In 2019: Prospects For De-Escalation Look Remote | Global Risk Insights". Global Risk Insights. https://globalriskinsights.com/2019/01/prospects-for-de-escalating-theconflict-in-eastern-ukraine/.
} 
summer destinations. Moreover, Putin's crusade of painting the construction of the Crimean Bridge as a national interest project aimed at unification as opposed to the division advocated for by western powers endeared him to the Russian majority as a focused leader. Consequently, the construction of the Crimean Bridge, though open to interpretation, fits into numerous political machinations engineered by Vladimir Putin to not only cement his legacy as a strong leader but also pave way for more ambitious plans yet to be revealed.

\section{CONCLUSION}

Russia's political and economic journey since the fall of the USSR has been one of the most intriguing in the world. The country has since recovered from one of the worst economic recessions in modern history and proceeded to become one of the world's biggest economies. However, Russia has also been the centre of global friction concerning its disregard for treaties, trade deals, and general global authority. In particular, Vladimir Putin's tenure as president from 1999 to 2008 and again from 2012 has epitomized Russia's turbulent relationship with the international community. Most recently, the annexation of Crimea and subsequent construction of the Crimean Bridge linking Crimea to Russia has been the focus of criticism and economic sanctions from the E.U and America. However, despite the international uproar, the bridge has largely served to portray Putin as a strong leader on three major fronts. He has used the bridge to create internal strife within Ukraine which would inturn paint him as a saviour in his bid to end the conflict. Secondly, by disregarding international pressure and putting up a strong front backed by military forces, the construction and completion of the bridge has cemented his legacy as a strong and unmovable leader of Russia. Finally, the construction of the bridge has in more ways than one served to advance Putin's political agenda in and outside Russia. In so doing, it can be argued that the Crimean Bridge has more symbolic significance relating to Vladimir Putin's unquestionable leadership capabilities than its role in easing transport of people and goods between Russia and Crimea.

\section{BIBLIOGRAPHY}

[1] Beznosiuk, Max. 2019. "The Ukraine Conflict In 2019: Prospects For De-Escalation Look Remote | Global Risk Insights". Global Risk Insights. https://globalriskinsights.com/2019/01/prospects-for-deescalating-the-conflict-in-eastern-ukraine/.

[2] Bond, David, Roman Olearchyk, and Max Seddon. 2019. "Russian Bridge To Crimea Strangles Ukraine Ports |Financial Times". Ft.Com. https://www.ft.com/content/f5c68dd4-765c-11e9-be7d-6d846537acab.

[3] Fokht, Elizaveta. 2019. "Is Putin's Popularity In Decline?". BBC News. https://www.bbc.com/news/worldeurope-48674705.

[4] Goncharenko, Roman. 2019. "Vladimir Putin's 'Crimea Effect' Ebbs Away 5 Years On | DW | 15.03.2019". DW.COM. https://www.dw.com/en/vladimir-putins-crimea-effect-ebbs-away-5-years-on/a47941002.

[5] Hodge, Nathan. 2018. "Russia's Bridge To Crimea: A Metaphor For The Putin Era". CNN. https://edition. cnn.com/2018/05/15/europe/russia-crimea-bridge-intl/index.html.

[6] Karatnycky, Adrian. 2005. "Ukraine's Orange Revolution". Foreign Affairs 84 (2): 35. doi:10.2307/ 20034274.

[7] Kolstø, Pål. 2016. "Crimea Vs. Donbas: How Putin Won Russian Nationalist Support-And Lost It Again". Slavic Review 75 (3): 702-725. doi:10.5612/slavicreview.75.3.0702.

[8] Lourie, Richard. 2018. "Putin'S Bridge Over Troubled Waters". The Globe and Mail. https://www.thegl obeandmail.com/opinion/article-putins-bridge-over-troubled-waters/.

[9] Luhn, Alec. 2015. "15 Years Of Vladimir Putin: 15 Ways He Has Changed Russia And The World". The Guardian. https://www.theguardian.com/world/2015/may/06/vladimir-putin-15-ways-he-changed-russiaworld.

[10] Satter, David. 2016. "Vladimir Putin \& 1999 Russian Apartment-House Bombings -- Was Putin Responsible? - By David Satter". Hudson.Org. https://www.hudson.org/research/12750-vladimir-putin1999-russian-apartment-house-bombings-was-putin-responsible.

[11] The Moscow Times. 2019. "Rebel Leader Says East Ukraine Wants To Join Russia - The Moscow Times". The Moscow Times. https://www.themoscowtimes.com/2019/04/09/rebel-leader-says-east-ukraine -wants-to-join-russia-a65162.

[12] The Moscow Times. 2019. "Russia Moves to Decriminalize 'Unavoidable' Corruption, Following Putin's Proposal". The Moscow Times. https:/www.themoscowtimes.com/2019/01/29/russia-moves-decriminalize -unavoidable-corruption-following-putins-proposal-a64316. 
[13] Times, The. 2019. "Russia's Crimean Annexation Cost Ukrainian Ports \$400M - FT - The Moscow Times". The Moscow Times. https://www.themoscowtimes.com/2019/05/17/russias-crimean-annexationcost-ukrainian-ports-400m-ft-a65625.

Citation: Sampson M. Nathanailidis. "The Crimean Bridge and Its Effect in Vladimir Putin's Image as a Strong Leader" International Journal of Political Science (IJPS), vol 7, no.1, 2021, pp. 34-38. doi: https://doi.org/10.20431/2454-9452.0701004.

Copyright: (c) 2021 Authors. This is an open-access article distributed under the terms of the Creative Commons Attribution License, which permits unrestricted use, distribution, and reproduction in any medium, provided the original author and source are credited. 